\title{
Relações Étnicas e Relações Raciais: diferenças e aproximações
}

\section{Ethnic Relations and Race Relations: differences and approximations}

Josildeth Gomes Consorte Pontifícia Universidade Católica de São Paulo (PUC-SP) josi.consorte@hotmail.com

DOI: $10.22481 /$ odeere.v4i8.6232

O tema de que me ocuparei, "relações étnicas e relações raciais: diferenças e aproximações", é muito caro à Antropologia na medida em que estas relações se inserem no âmago da sua preocupação central - a diversidade humana característica iniludível da nossa espécie.

Começarei por defini-las, ainda que sumariamente.

As relações raciais são frutos da nossa diversidade física (estatura, cor da pele, cor e qualidade do cabelo, forma do nariz, forma e cor dos olhos, espessura dos lábios) incidindo sobre nossa aparência. Quando falamos de raças estamos pensando basicamente na aparência das pessoas a quem estamos nos referindo. Quando falamos de relações étnicas, não. As relações étnicas são construídas a 
partir da inclusão de outros parâmetros, todavia, não menos significativos. Por que não menos significativos? Porque o impacto das relações étnicas é praticamente tão grande quando o impacto das relações raciais na vida dos grupos. Um grupo étnico resulta da conjunção de um grupo de pessoas ocupantes de um território, falantes de uma mesma língua, empenhadas no processo de produção das suas existências.

Portanto, grupo, território e língua são os elementos indispensáveis para que se possa falar de um grupo étnico. Quando falamos de grupo étnico estamos falando de um povo e da sua cultura, ou seja, de um outro tipo de diversidade, uma diversidade cultural. Raça e cultura aparecem sempre associados. Não obstante, como nos ensinou Franz Boas, aquele notável antropólogo americano de origem alemã, professor da Universidade de Columbia, não existe ligação necessária entre raça e cultura, a raça não determina a cultura, nem a cultura determina a raça. Ou seja, não existe determinismo cultural ou racial, uma constatação preciosa para nossa Antropologia. Os grupos étnicos, estão presentes na formação de todas as nações. Quando nós olhamos para um mapa do mundo e vemos aquelas manchas coloridas correspondentes às diversas nações, aos países que existem sobre a terra, todos eles são formados por grupos étnicos, em maior ou menor número. Algumas nações foram formadas de um pequeno número de grupos étnicos, outras de um grande número. Quanto maior o número de grupos étnicos, também chamados de comunidades étnicas presentes numa nação, tanto maior a diversidade humana de que ela se constitui. As relações entre os grupos étnicos nem sempre são as mais cordiais, basta abrir um jornal para ver os conflitos que rolam pelo mundo.

As migrações, um fenômeno tão comum em nossa época, são frequentemente resultantes desses conflitos, exatamente porque "o outro", o diverso de "nós", de alguma forma sempre representa uma ameaça. Nós temos, enquanto humanos, uma dificuldade enorme de conviver com a alteridade. Isso nos coloca diante de uma situação extremamente difícil, dado que a diversidade é uma constante entre nós, tanto no plano cultural quanto no plano biológico.

Falando dos grupos étnicos e das relações étnicas entre nós. Somos um povo em formação, a partir de vários grupos étnicos: os grupos indígenas que se encontravam aqui, em grande parte dizimados, mas ainda presentes, sobretudo 
na Amazônia e no Centro Oeste; os grupos formados pelos africanos trazidos pelo comércio escravo; os colonizadores europeus (portugueses e outras nacionalidades, visto que tivemos várias tentativas de ocupação do nosso território por outros grupos). Tivemos os holandeses, por vinte e cinco anos, na região de Pernambuco e também os franceses no Maranhão. Além disso, tivemos no século XIX uma política de imigração europeia, mas também de orientais, japoneses em sua maioria. A nossa diversidade é verdadeiramente grande e cada região, a depender dos contingentes humanos que recebeu, vai ter uma feição característica diferente da outra. O Brasil é mais branco no Sul do que no Nordeste, é mais indígena na Amazônia e é mais negro na Bahia, no Rio de Janeiro, em Minas Gerais, Pernambuco, Maranhão e seus vizinhos.

No caso dos povos africanos, já que estamos falando na pertença afro, é importante ressaltar que o comércio de escravos durou centenas de anos introduzindo inúmeros grupos étnicos ao longo desse tempo por todo território. Com eles também chegaram diferentes formas de ser, de sentir, de acreditar, de produzir a sobrevivência. Mão de obra de escravos expropriados da sua condição de pessoas, de seus modos de ser e sentir, não obstante esta condição, de alguma forma também se fizeram presentes em nossa formação. Nós somos, assim, um país formado por um grande contingente africano, muito embora apesar dessa presença, sejamos um país racista e preconceituoso, sobretudo em relação aos negros e afrodescendentes. A tomada de consciência da realidade desta pertença é fundamental para que os negros, sobretudo os jovens possam, no futuro deixar de ser a parcela mais sofrida da nossa população.

Neste particular, o trabalho realizado pelo Órgão de Educação e Relações Étnicas - ODEERE, que Marise de Santana vem desenvolvendo ao longo desses anos, é da maior importância, porque a preocupação com a pertença afrobrasileira vai necessariamente levar em consideração os vários ângulos dessa pertença e refletir sobre os diferentes modos de enfrentar essa realidade, dos quais a educação é, sem dúvida o mais importante.

\section{Raça e cultura}

As relações entre raça e cultura marcam, fundamentalmente, o início da reflexão que vai dar origem à Antropologia. A diversidade humana é toda ela 
construída a partir da combinação das características raciais e culturais dos povos que hoje, como no passado vêm habitando o planeta. De que natureza são elas? Em que medida as explicam?

O culturalismo foi a abordagem que no âmbito da Antropologia se ocupou destas questões. Desde sempre, as relações entre o biológico e o cultural estiveram na mira dos antropólogos. E na medida em que a produção da cultura se impôs como a característica decisiva dos humanos, a compreensão da sua relação com o biológico também se tornou essencial à compreensão da diversidade cultural. Não apenas toda a construção do conhecimento antropológico se deu a partir desta preocupação, como, neste processo apontar qual a dimensão é proveniente na explicação da diversidade humana se tornou o desafio fundamental. O pressuposto da existência da relação entre raça e cultura, não podia ser colocada em dúvida, teríamos sempre que procurá-la, mas certamente não era uma relação necessária. A afirmação de Boas neste sentido, foi sem dúvida um divisor de águas para os rumos da Antropologia.

\section{Relações Étnicas e Relações Raciais}

A diversidade humana, temática de origem e por isto mesmo crucial da Antropologia, tem sido objeto de inúmeras abordagens ao longo da história da nossa disciplina. Quer se trate da diversidade física ou biológica, quer se trate de costumes ou modos de ser ou existir, o interesse em compreender suas origens, suas relações e suas razões de ser tem motivado antropólogos das mais diversas orientações teóricas. Raça e etnia tem sido, assim, conceitos dos mais significativos para expressar a natureza das relações entre os grupos humanos. De natureza eminentemente biológica, o termo raça, tomando como referência a combinação de traços físicos (cor da pele, qualidade do cabelo, forma dos olhos, do nariz, dos lábios, estatura) tem sido responsável pela classificação de grupos humanos situados em diferentes áreas do planeta. Raça supõe origem biológica, descendência. Etnia, por sua vez, sem excluir os traços físicos, parte do conjunto de elementos essenciais à formação de um agregado humano, uma unidade constituída de povo, língua e território, unidos na produção de um modo de existir - uma cultura. 
Apesar de sua diversidade, raças não são humanidades diferentes. Todavia não há relação necessária entre raça e cultura. O biológico não determina o cultural. As diferenças físicas resultam de respostas adaptativas a diferentes ambientes geográficos que por sua vez resultam em diferentes respostas culturais que não são necessariamente as mesmas. Os de pele escuras, os negros, não falam línguas diferentes por exigências do meio geográfico em que vivem. Isso vale para todos, os de pele branca, amarela ou de qualquer cor.

Josildeth Gomes Consorte: Foi a primeira pesquisadora contratada pelo Centro Brasileiro de Pesquisas Educacionais (CBPE), criado e dirigido por Anísio Teixeira (Rio de Janeiro, 1955). É sócia fundadora da Associação Brasileira de Antropologia (ABA desde1955) e Doutora Honoris Causa pela Universidade Estadual do Sudoeste da Bahia (UESB). Participou do Projeto Estado da Bahia Universidade de Columbia, dirigido por Anisio Teixeira entre 1950 e 1952. É professora titular da Pontifícia Universidade Católica de São Paulo desde 1964, sendo uma das responsáveis pelo "ciclo básico" na PUC-SP. Seu interesse envolve diversas áreas do conhecimento da Antropologia como Educação, Manifestações Religiosas Brasileiras e Relações Étnicas. Nasceu em Salvador (BA), em 21/06/30, como Josildeth da Silva Gomes. Ali fez seus estudos de primeiro grau e nível médio (normalista), tendo iniciado sua vida profissional como professora primária em escolas locais. É bacharel em Geografia e História pela Universidade Federal da Bahia (1951) e licenciada em Geografia e História pela Universidade do Brasil, atual Universidade Federal do Rio de Janeiro (1957). Cursou as sequencias de Antropologia e Sociologia na Fundação Escola de Sociologia e Política de São Paulo (1952). Fez sua pós-graduação em Antropologia nas Universidades de Columbia (New York ? EUA) e Chicago (Chicago-EUA) entre 1953 e 1955. Doutorou-se em Ciências Humanas pela Pontifícia Universidade Católica de São Paulo (PUC-SP, 1973), em cujo o corpo docente ingressou em 1966. É professora Titular desta mesma Universidade desde 1984.

This work is licensed under a Creative Commons Attribution 4.0 International License.

Este trabalho está licenciado com uma Licença Creative Commons - Atribuição 4.0

Internacional.

Artigo recebido para publicação em: Dezembro de 2019.

Artigo aprovado para publicação em: Dezembro de 2019. 